of the recently published work "Naven" (see NaturE of March 13, p. 454) in which he gives an account of some of his observations among the Iatmul tribes in an expedition to the Sepik River, New Guinea, in 1933, and elaborates an extension of the 'functional' method in sociological investigation.

\section{Iron and Steel Institute: Bessemer Gold Medals}

The Bessemer Gold Medals for 1937 of the Iron and Steel Institute have been awarded to Colonel N. T. Belaiew and Aloyse Meyer. Colonel Belaiew of Paris, a former pupil of Prof. Tschernoff of the Military Academy, Petrograd, has, during the last twenty-five years, published a number of papers of outstanding importance on metallurgy. These have dealt mainly with the crystallization of metals, and in particular steel. His studies of the constitution and solid geometry of pearlite, sorbite and troostite demonstrated the true width of the lamellæ in these structures and the relation between the angle of section and the apparent width. His suggestion of a definite unit of crystal size of iron has been confirmed from other sources. He also studied the primary and secondary crystallization in steel and the origin of the 'Widmanstätten' structure in steel and meteorites. His insight is strikingly shown by his insistence on 'granulation' in the austenitic zone, the explanation of which has been provided by the subsequent discovery of the delta-gamma change in iron at very high temperatures. He has studied the manufacture and uses of Damascene steel and related the results to the manufacture of high-class steels at the present time, in particular high-speed steel.

M. Aloyse Meyen, of Luxemburg, is an honorary vice-president of the Institute, and is well known as head of the Société Anonyme ARBED, the great Luxemburg combine and the second largest iron and steel company in Europe. He has rendered unique services to the iron and steel industry as president, since 1928, of the Entente Internationale de l'Acier. In addition, his encouragement of the acquisition and diffusion of technical information and metallurgical knowledge in the Luxemburg-Lorraine district has been invaluable to the progress of the industry; he was actively connected with the introduction of the Thomas-Gilchrist process of steel manufacture into the district-the Hauts Fourneaux et Acieries de Dudelange was one of the first works in Europe and the first in the Luxemburg-Lorraine district to adopt this method, which revolutionized the manufacture of steel on the Continent. Since the Great War, he has been responsible for the introduction of modern American blast-furnace practice in the works under his control.

\section{Richard Anthony Proctor (I837-I888)}

IN the mid-Victorian era there were no more popular books on astronomy than those of Richard Anthony Proctor, the centenary of whose birth falls on March 23. Possessing a remarkable power of lucid exposition and almost unbounded energy, in his comparatively short life he published about sixty separate works, wrote numerous memoirs and delivered many lectures in Great Britain, the United States and Australia. He was, however, no mere exponent, and in the little leisure he enjoyed he studied the planet Mars, plotted on a single chart the 324,198 stars of Argelander's "Durchmusterung" and made the important discovery of 'star-drift'. Proctor was the son of a London solicitor and was born in Cheyne Row, Chelsea. His father died in 1850 and left the family ill-provided for ; so Proctor became a clerk in the London and Joint Stock Bank, but was able after a year or two to study at the University of London; at the age of nineteen years he entered St. John's College, Cambridge, graduating as 23rd Wrangler in 1860. He then read for the law, but this was soon abandoned for science, and in 1865 he published his first book, "Saturn and its System".

Proctor married before leaving Cambridge and for a time was in pecuniary difficulties. In 1868 he scored his first financial success with his "Half Hours with the Telescope". This was followed by his "Other Worlds than Ours". It was about the time this appeared that after working five years without a holiday he wrote, "I would willingly have turned to stone-breaking or any other form of hard and honest but unscientific labour if a modest competence in any such direction had been offered me." For a short time he taught mathematics in a school at Woolwich. He was elected a fellow of the Royal Astronomical Society in 1866; in 1872 he became honorary secretary to the Society, but this he resigned in order to undertake a lecture tour in America. The tour was a success and in 1879 , after the death of his wife, he made a tour to Australia. In 1881 he founded the periodical Knowledge, and then returned to the United States, marrying a widow, Mrs. Crawley, and settling at St. Joseph, Missouri. A few years later he transferred his house and observatory to Florida. In September 1888 he was about to sail from New York on a visit to England but was attacked by fever and died in hospital on September 12, at the age of fifty-one years.

\section{Printing and Allied Trades Research Laboratories}

THe new Laboratories of the Printing and Allied Trades Research Association were officially opened by H.R.H. the Duke of Gloucester on March 9 in the presence of the Advisory Council of the Department of Scientific and Industrial Research and the Council and members of the Research Association. The laboratories are situated just off Fleet Street in the centre of London's printing district, and comprise about seven thousand square feet devoted to chemical and physical laboratories, library and offices for the investigation of the major and the day-to-day problems of the printing, newspaper, ink and paper industries. The basement has been converted into an optics laboratory for colour measurement in connexion with colour printing and the measurement of the opacity of paper, etc. A strong-room in the basement has been converted into a constant humidity laboratory where the temperature and relative humidity are maintained at $65^{\circ} \mathrm{F}$. and 65 per cent. 
All paper-testing work, on strength and printing quality, is carried out in this laboratory, where is also installed a small printing machine on which printing tests can be carried out under controlled conditions.

GEneral offices and library are housed on the ground floor of the Laboratories. From the library, the Intelligence Section of the Association's work is operated and the "Review of Literature" published. The physics department is contained on the first floor where work on colour fading, examination of adhesives and bookbinding materials are carried out. This department also contains a section for photomicrographic work on paper fibres, inks, prints and printing alloys, and a dark room for ultra-violet and infra-red work. The upper floor has been converted into two chemical laboratories. One is mainly for analytical work in connexion with the day-to-day problems submitted by member firms, and the other set aside as a chemical research laboratory for dealing with the longer-ranged problems connected with the working properties and drying of printing inks, lithography, photogravure printing, stereotyping and electrotyping, etc. It is the aim of the Research Association to deal with both the day-to-day problems and the longer-ranged work connected with printing processes and raw materials, and to build up a scientific background to one of the 'craft' industries so that the inherent difficulties, now aggravated by increased speeds of production, can be eradicated and the future developments of the industry guided by scientific research.

\section{The West Indian Volcanoes}

Ат the Friday evening discourse delivered at the Royal Institution on March 12, Sir Gerald P. LenoxConyngham described "Montserrat and the West Indian Volcanoes". The island of Montserrat has recently suffered from a series of earthquakes. They began about the beginning of 1934 and continued with varying intensity all through 1934 and 1935. In the autumn of 1935 the inhabitants sent a petition to the Governor praying that steps should be taken to discover, if possible, whether there was danger of an eruption. Their anxiety was due to their recollection of the events of 1902 when eruptions of the Soufrière of St. Vincent and of Mont Pele of Martinique did terrible damage. Such an eruption in Montserrat would be most dangerous to the town of Plymouth. As a result of the petition, a small expedition consisting of a geologist and a physicist was sent out. Frequent severe shocks were felt up to November 1935. After that date the activity of the volcano became steadily less. A good measure of success was attained in locating the positions of the foci, and it is now known that they were all situated in a belt about four miles wide which crosses the island from south-west to north-east. The West Indian island arc bears strong resemblance to the East Indian are that runs eastwards from Java. In 1929-30 Dr. Vening Meinesz of the Dutch Geodetic Commission made a gravity survey of the seas around these islands and found that there is a belt of negative gravity anomaly lying outside the island arc. The circular form of island and mountain ares is suggestive. It is probable that the form is determined by the intersection of a thrust plane with the sphere. $\mathrm{Mr}$. $P$. Lake has pointed out that the radius of the arc gives the dip of the fault where the thrust plane cuts the surface. It is believed that gravity determinations combined with the consideration of the curvature of the island chain and of the probable position of the over-thrusting foot of the tectonic are on which the islands have been built up by voleanic agency will throw light on the structure of the region.

\section{New University Studies}

AT the recent annual meeting of the Court of Governors of the University of Birmingham, the vice-chancellor, Sir Charles Grant Robertson, noted a small decline in the number of students in the University, possibly due to the decline in the birthrate (though periods of 'boom' in trade have on previous occasions been associated with a slackening in the entry to the University). The Faculty of Medicine, however, shows no such falling off. $\mathrm{He}$ commented with satisfaction on the success of the Appointments Board and the evidence of an increasing demand for the product of the University in industry--in fact, during the past year the demand on the Appointments Board exceeded the supply. Sir Charles dealt with the lack of the study of the social sciences in English universities. It has been suggested that the education of a university graduate is incomplete without some such study, but there is the difficulty of finding the time without omitting some other part of the curriculum. It appears probable that little can be done unless there is a specialist social science degree course, or the subject is made one for a post-graduate course of at least one year; and then there is the problem of finding posts for such graduates, with adequate pay and prospects of promotion, so long as the wide field of municipal civil service is barred to university graduates. Sir Charles expressed sympathy with the Government's desire to promote physical training in universities, but, in addition to the fact that the necessary trainers do not at present exist, the thorny problem of compulsion or non-compulsion would have to be solved.

\section{The Universities and Social Science}

A SPEECH entitled "A Citizen Challenges the Universities", delivered by Sir Ernest Simon at the summer, 1936, meeting of the Council of the Association of University Teachers in Cardiff, appeared in the Universities Review of November last, and a reprint of it has reached us. The challenge relates to the imminent threat to democracy involved in our tolerance of such conditions as those of South Wales and other depressed areas, and the universities' alleged neglect, in the face of that threat, to do their duty by the social sciences: their failure alike to provide adequate inducements, staff and equipment for research in those sciences and for specialized study in them, and to employ effectual measures for ensuring that students, of whatever schools, shall 